Е. С. Куйкина

Петрозаводск

DOI: 10.15393/j9.art.2011.304

\section{ПОВЕСТЬ «ВЫБОР КРЕСТА» В. А. ЖУКОВСКОГО}

\ух поэта тайно соприсутствует в его создании. Так ут$\leftrightarrow$ верждал В. Жуковский, понимая дух поэта как некую сущность, которая животворит произведение. «И если он есть дух чистоты», то этой благотворной чистотой «безотчетно и неуловимо» проникнуто и его художественное создание ${ }^{1}$. Так, в поэзии В. Жуковского отражается его духовный мир, устремления его души к нетленным ценностям христианства, к познанию предназначения человеческой жизни, к вере.

В 1845 году В. Жуковский переводит повесть немецкого автора А. Шамиссо «Выбор креста»². Для перевода В. Жуковский выбирал лишь то, что, по словам А. Н. Веселовского, «отвечало его внутреннему содержанию, потребности его выразить» ${ }^{3}$.

(C) Куйкина Е. С., 2011

1 Жуковский В. А. Полн. собр. соч.: В 12 т. / Под ред. проф. А. С. Архангельского. СПб., 1902. Т. 10. С. 85.

${ }^{2}$ А. Н. Веселовский рассматривает произведение с биографической стороны и указывает на то, что причиной обращения к переводу повести была семейная драма поэта, «когда он падает под тяжестью семейного креста» (Веселовский А. Н. В. А. Жуковский. Поэзия чувства и «сердечного воображения». М., 1999. С. 14). А. С. Янушкевич обращает внимание на эту повесть как на одну из ступеней на пути В. Жуковского к эпосу, к переводу «Одиссеи» Гомера (Янушкевич А. С. Путь Жуковского к эпосу // Жуковский и русская культура. Л., 1987. С. 177-178).

${ }^{3}$ Веселовский А. Н. Указ. соч. С. 14.
Повесть начинается словами:

Усталый шел крутой горою путник;

С усилием передвигая ноги,

По гладким он скалам горы тащился

И наконец достиг ея вершины ${ }^{4}$.

Перед нами странник, направляющий свой путь из неведомых земель в высокие горы. Мы не знаем ни его возраста, ни имени. Он утомлен от долгого пути, и жизнь едва теплится в его изнуренном трудом теле. Думается, что в образе этого усталого путника несколько обобщенно представлена человеческая жизнь.

А. С. Янушкевич, анализируя особенности поздних произведений Жуковского, обращает внимание на слова поэта в повести «Мудрец Керим», где он так определяет «смысл человеческого существования»:

Вся наша жизнь есть странствие по свету ${ }^{5}$.

Примечательны на этот счет слова Святителя Игнатия Брянчанинова (XIX век), обращенные к одному из духовных чад:

Благополучно ли вы совершаете ваше земное странствование ${ }^{6}$

И далее добавляет, что конечным итогом странствования человека по свету является Вечность. А в творении «Слово о человеке» Святитель также пишет:

Земная жизнь каждого человека есть время, данное ему на покаяние. Все человечество на земле должно быть погружено в покаяние, в неутешное рыдание. Оно должно странствовать на ней, не прилепляясь сердцем ни к каким предметам, которыми обставлена эта гостиница, но непрестанно помышляя о горнем своем отечестве и всесильно стремясь возвратиться в него ${ }^{7}$

${ }_{4}^{4}$ Жуковский В. А. Полн. собр. соч.: В 12 т. Т. 4. С. 47. Далее цитируем по этому изданию с указанием тома - римской и странищ арабскими цифрами.

${ }^{5}$ Янушкевич А. С. Указ. соч. С. 178.

${ }^{6}$ Свт. Игнатий (Брянчанинов). Письма о подвижнической жизни. Paris; M., 1995. C. 153

${ }^{7}$ Он же. Слово о человеке. СПб., 1995. С. 54. 
Такие мысли очень близки В. А. Жуковскому. Он старался осмыслить жизнь с христианской точки зрения. Стремление увидеть свое земное предназначение, свое место, уготованное каждому человеку Создателем, отражается в дневниковых записях поэта, письмах, публицистике, художественных произведениях.

«Для чего мы здесь?» - вопрошает Жуковский в одном из писем к Н. В. Гоголю. Задав такой вопрос, он сам далее дает на него ответ, ответ, полный веры и христианского смирения:

Мы здесь для Бога. Тот, Кто, создав нас, вложил в нашу душу стремление Его постигнуть и с Ним соединиться, не мог нас ни для чего иного создать, как для Самого Себя (X, 79).

\section{И далее:}

Мы созданы Богом для Бога, мы помещены Им в әтом мире... чтобы... постоянно искать Бога, неизменно к Нему стремиться и в Нем одном пребывать мыслию, волею и действием $(\mathrm{X}, 79)$.

Чтобы душу свою очистить от всего временного и тленного, возвысить и с нею «на всю вечность» перейти «в иную, высшую жизнь».

Не случайно путник в повести «Выбор креста» идет в высокие горы. Это «горний» путь, это путь веры, путь устремленности человека в небо, путь подвига, путь страданий.

Далее мы читаем, что, совершив вечернюю молитву, странник уснул. И во сне этот человек обращается к своему Создателю с просьбой облегчить тяжесть его земных страданий:

Отец! <..>

Я знаю: каждый, кто здесь от жены

Рожден, свой крест нести покорно должен;

Но тяжестью не все кресты равны;

Мой слишком мне тяжел, не по моим

Он силам; облегчи его, иль он

Меня раздавит и моя душа

Погибнет.

В Евангелии от Матфея есть слова Господа Иисуса Христа, обращенные к ученикам:

Если кто хочет идти за Мною, отвергнись себя, и возьми крест свой, и следуй за Мною (Мф. 16:24).
Духовные наставники Свято-Троицкой Сергиевой Лавры в книге «Троицкие листки. Духовно-нравственное чтение для народа» так поясняют слова Христа:

Аще кто хощет по Мне ити, кто хочет быть Моим последователем и учеником не на словах, а на деле, - а это для всякого возможно, была бы только на то добрая воля человека, тот, да отвержется себе, пусть забудет свое самолюбие, u возьлет крест свой, как Я взял Мой крест, и по Мне гря$\partial е m$, пусть идет за Мною туда, куда Я несу Мой крест. Кто хочет быть участником моей славы, тот пусть будет участником и в Моих страданиях, через терпение всего скорбного, даже до смерти 8 .

В. Жуковский глубоко воспринял слова Спасителя о несении креста. В одном из писем, обращенных к своему духовному отцу иерею Иоанну Базарову, он пишет о смиренном преодолении земных скорбей и перенесении несчастий, связанных с потерей близких людей:

Так Богу угодно! <..> Помоги вам Податель креста нести

Им поданный крест и быть пред Ним в минуты Его испытания таким, как Он того требует!

Подвиг самоотвержения, по словам Жуковского, возможен благодаря осознанию человеком своей «ничтожности» и «несказанного блаженства... нашей принадлежности Богу» (X, 79).

Мысли о греховности человеческого существа и смирении мы находим в поучениях Святителя Игнатия Брянчанинова. По словам Святителя, «взятие креста своего есть признание себя достойным посылаемых на нас скорбей» ${ }^{10}$.

В повести Жуковского герой чудесной силой перемещается в небесный храм, где ему милостивый Создатель предоставляет возможность выбора:

Перед тобою все кресты земные

Здесь собраны; какой ты сам из них

Захочешь взять, тот и возьми.

8 Троицкие листки. Духовно-нравственное чтение для народа. Толкование на Евангелие от Матфея. М., 1994. С. 409-410.

${ }^{9}$ Цит. по кн.: В. А. Жуковский в воспоминаниях современников. М., 1999. C. 448

${ }^{10}$ Свт. Игнатий (Брянчанинов). Указ. соч. С. 78 
Герой-странник увидел множество крестов. Он испытывал тяжесть каждого их них и клал на плечи, «дабы узнать, какой нести удобней», однако не был доволен представленным. В итоге его выбор остановился на кресте, который он уже нес, кресте, который был определен ему Богом.

$$
\begin{aligned}
& \text { Был нелегок он; правда, был из твердой } \\
& \text { Сработан пальмы; но зато, как будто } \\
& \text { По мерке для него был сделан, так } \\
& \text { Ему пришелся по плечу он ловко. } \\
& \text { И он воскликнул: Господи! позволь мне } \\
& \text { Взять этот крест. И взял. Но что же? - Он } \\
& \text { Был самый тот, который он уж нес. }
\end{aligned}
$$

В этих заключительных строках повести звучит вера в благость Божественного Провидения, вера в заботу Творца о Своем создании.

Примечательны слова Святителя Иоанна Златоуста (IV век), призывающего нас:

Будем принимать все, постигающее нас, с благодарностью к Тому, Кто лучше всего знает, что нам полезно, и Кто любит нас сильнее самих родителей ${ }^{11}$.

В этом высказывании Святителя живет вера в ободряющие слова Господа:

Придите ко Мне все труждающиеся и обремененные, и Я упокою вас; возьмите иго Мое на себя и научитесь от Меня, ибо Я кроток и смирен сердцем, и найдете покой душам вашим; ибо иго Мое благо и бремя Мое легко (Мф. 11:28-30).

Не случайным, на наш взгляд, является то, что странник в повести Жуковского засыпает и жалоба на земной крест и тяжесть существования возникает у героя именно во сне. Думается, что это не столько физический сон, во время которого тело человеческое получает отдохновение, сколько духовный. Об этом духовном сне Господь через Евангелие предупреждает Своих последователей. В месте, называемом Гефсимания, не раз Он обращался к ученикам, находя их спящими:

Бодрствуйте и молитесь, чтобы не впасть в искушение: дух бодр, плоть же немощна (Мф. 26:41).

${ }^{11}$ Свт. Иоанн Златоуст (Архиеп. Константинопольский). Избранные творения. М., 1993. Т. 1. Толкование на Евангелие от Матфея. С. 109
Также о духовном сне говорится и в притче о рабе, ожидающем Господина:

Итак бодрствуйте, потому что не знаете, в который час Господь ваш придет. Но это вы знаете, что, если бы ведал хозяин дома, в какую стражу придет вор, то бодрствовал бы и не дал бы подкопать дома своего (Мф. 24:42, 43).

В заключение вспомним слова В. А. Жуковского. В одном из писем к Гоголю он говорит о том, что душа поэта должна быть «светлая, чистая, младенчески верующая»:

Тогда его поэзии предаешься без всякой тревоги, с ним вместе веруешь святому, любишь добро, постигаешь красоту, и знаешь, какое назначение души твоей $(\mathrm{X}, 85-86)$.

Жуковский не случайно перевел повесть Шамиссо на русский язык. Духовное содержание этой повести было близко поэту, созвучно его устремленности к вере, к познанию христианских ценностей. Эта устремленность сопровождала поэта всю жизнь. 